\title{
Physico-Chemical, Microbiological and Sensory Characteristics of Yogurt as Affected by Added Lactose
}

\author{
Behannis Mena1, Kayanush Aryana2 ${ }^{2 *}$ \\ ${ }^{1}$ School of Agriculture and Food, Faculty of Veterinary and Agricultural Sciences, The University of Melbourne, Melbourne, Australia \\ ${ }^{2}$ School of Nutrition and Food Sciences, Louisiana State University Agricultural Center, Baton Rouge, USA \\ Email: ${ }^{*}$ karyana@agcenter.1su.edu
}

How to cite this paper: Mena, B. and Aryana, K. (2019) Physico-Chemical, Microbiological and Sensory Characteristics of Yogurt as Affected by Added Lactose. Food and Nutrition Sciences, 10, 1243-1262. https://doi.org/10.4236/fns.2019.1010090

Received: September 17, 2019

Accepted: October 27, 2019

Published: October 30, 2019

Copyright $\odot 2019$ by author(s) and Scientific Research Publishing Inc. This work is licensed under the Creative Commons Attribution International License (CC BY 4.0).

http://creativecommons.org/licenses/by/4.0/ (c) (i) Open Access

\begin{abstract}
Enrichment of yogurt with lactose addition may increase the growth of the yogurt starter culture (Streptococcus thermophilus and Lactobacillus delbrueckii ssp. bulgaricus) and enhance yogurt physico-chemical and sensory attributes. The objectives of this study were to determine the influence of added lactose on the 1) physico-chemical characteristics, including the final lactose content of yogurt, during its shelf life; 2) growth of the yogurt starter culture over yogurt shelf life and 3) the sensory attributes of yogurt. Fat free plain set-type yogurt was manufactured using $0 \%, 1 \%, 3 \%$ and $5 \% \mathrm{w} / \mathrm{w}$ added lactose to accomplish objectives 1 and 2. For objective 3, a blueberry yogurt was manufactured using the same lactose levels. Analyses for plain set-type yogurt were conducted at 7 days intervals during 35 days of storage. Sensory evaluation was conducted on flavored yogurt three days after its manufacture. Data were analyzed using Proc Mixed model of SAS ${ }^{\oplus} 9.3$ program. Significant differences between means were analyzed at $\alpha=0.05$ using Tukey adjustment. Lactose addition influenced some of the yogurt characteristics in a positive manner. Lactose contents of yogurts with lactose added at 1\%, 3\% and 5\% stayed higher in that proportion than control throughout the 35 days of storage. Yogurts containing 5\% w/w added lactose had the lowest $\mathrm{pH}$. Yogurts containing $5 \% \mathrm{w} / \mathrm{w}$ added lactose had significantly the highest syneresis values compared to $0 \%, 1 \%$ and $3 \% \mathrm{w} / \mathrm{w}$ added lactose during storage period at day 7 and from day 21 onwards. Use of 5\% w/w added lactose resulted in significantly higher counts of Streptococcus thermophilus compared to control and this bacterial survival was the highest for $1 \% \mathrm{w} / \mathrm{w}$ added lactose compared to the rest. The overall liking scores indicated that yogurts containing added lactose were preferred over control. For taste, sourness and sweetness samples containing added lactose had higher scores than control. The consumer ac-
\end{abstract}


ceptability of yogurts increased as lactose addition increased. The acceptability of yogurts and purchase intent frequency scores markedly increased with the addition of lactose.

\section{Keywords}

Added Lactose, Yogurt, Probiotic Properties, Starter Culture, Lactic Acid Bacteria

\section{Introduction}

Yogurt is a popular dairy product in the US and globally. The US Code of Federal Regulation describes yogurt as a cultured food that contains the lactic acid-producing bacteria Lactobacillus bulgaricus and Streptococcus thermophilus [1]. Yogurt starter cultures use lactose as a source of energy, fermenting it to lactic acid. These strains have a synergistic effect of one over the other. Initially Streptococcus thermophilus grows faster than Lactobacillus bulgaricus and releases lactic acid creating an acidic environment that favors the growth of Lactobacillus bulgaricus. Streptococcus thermophilus also produces formic acid and carbon dioxide $\left(\mathrm{CO}_{2}\right)$ which stimulate the growth of Lactobacillus bulgaricus. The later has a high proteinase activity to produce peptides that are utilized by Streptococcus thermophilus which acts on the peptides and releases free amino acids that are utilized by both microorganisms [2]. Yogurt starter culture is considered to have probiotic properties and yogurt is a fermented food matrix desirable for delivery of probiotics [3].

Lactose also known as "milk sugar" is a disaccharide carbohydrate, composed of two monosaccharide components: D-glucose and D-galactose [4]. Lactose is the most abundant constituent and main carbohydrate in bovine milk, crucial in the lactic acid fermentation of yogurt and other acid-coagulated dairy products [5]. It can be used as sweetener in low-calorie products. $\beta$-galactosidase is added to lactose into glucose and galactose, which are much sweeter than lactose itself [6]. Lactose is important for the metabolic activities of lactic acid bacteria and has a beneficial role in the manufacture of fermented dairy products. The amount of sugar added to yogurt milk should not exceed $9 \%$ because it may inhibit culture growth [7]. Lactic acid is one of the flavor compounds in yogurt. Lactose utilization is the primary function of lactic acid bacteria used in industrial dairy fermentations [8]. Lactic acid bacteria convert lactose into lactic acid, which reacts with proteins in the milk, causing them to precipitate at $\mathrm{pH}$ 4.6, and make the milk creamier. The lactic acid has a sour taste, which causes a change in flavor of the fermented product, e.g. yogurt and cheese.

The $\mathrm{pH}$ is an important quality attribute of yogurt as it defines the endpoint of fermentation process [9]. Lactose is converted to lactic acid by the fermentation process conducted by lactic acid bacteria, which drops milk pH from 6.7 to 4.2 - 
4.6 [10]. When the $\mathrm{pH}$ end point of 4.5 is achieved, the yogurt mixture is cooled to slow the reaction. Incorrect $\mathrm{pH}$ levels can lead to excessive free whey production and excess or insufficient tartness [11]. Titratable acidity is the total acid concentration in a food and is an important predictor of how organic acids influence flavor [12]. Yogurt has a titratable acidity of not less than $0.9 \%$, expressed as lactic acid [2].

Viscosity of yogurt is greatly influenced by the total solids content of milk to be used, especially the protein content [6]. Rotational viscometers, such as the Brookfield viscometer, are often used to describe the flow behavior of yogurts [6]. Syneresis or spontaneous whey separation on the surface of set yogurt is regarded as a defect [13]. This problem can be reduced by increasing the milk solids content to approximately 15\% [14] [15]. Homogenization improves the consistency and viscosity of yogurt, thus a greater stability to syneresis can be obtained [14] [16] [17]. However, [18] reported that homogenization has an adverse impact on yogurt with a lower fat content; it increases syneresis reducing water holding capacity due to empty spaces between casein matrices, and lack of native milk-fat globule membrane (FGM). Nonfat yogurt is normally low in total solids ( $10 \%$ to $12 \%$ ) and consequently suffers from whey separation or syneresis [19]. Reference [20] developed a method for the measurement of spontaneous whey separation in set type yogurt called the siphon method. This method determines the level of spontaneous whey separated on the surface of gels. By comparing three methods (drainage, centrifugation and siphon), the siphon method would be more appropriate in the determination of spontaneous whey separation level on the surface of set yogurt [13].

Lactose is an important energy source for yogurt culture bacteria. How added lactose would influence the characteristics of this important dairy product is not clearly understood. The aims of this study were to determine the influence of added lactose at various concentrations on the final lactose content, physicochemical, microbiological and sensory characteristics of yogurt.

\section{Materials and Methods}

\subsection{Yogurt Manufacture}

Two types of yogurt were manufactured. The first type was lactose added "plain" set yogurt. The second type was lactose added blueberry yogurt for the sensory study. Plain set-type yogurt was manufactured according to earlier published methods [21] [22] [23]. Briefly, the yogurt mixes contained skim milk and added lactose at $0 \%, 1 \%, 3 \%$ and $5 \% \mathrm{w} / \mathrm{w}$. The yogurt mixes were preheated to $60^{\circ} \mathrm{C}$ then homogenized in a two-stage homogenizer (Type: 300 DJP4 2PS, Gaulin, Manton-Gaulin MFG Co Inc., Everett, MA, USA) at $13.8 \mathrm{MPa}$ for the first stage and $3.45 \mathrm{MPa}$ for the second stage and later pasteurized at $85^{\circ} \mathrm{C}$ for 30 minutes. Yogurt mixes were tempered to $40^{\circ} \mathrm{C}$ and inoculated. Freshly thawed frozen yogurt starter culture concentrate of Streptococcus thermophilus (ST-M5) and Lactobacillus delbrueckii ssp. bulgaricus (LB-12) (CH-3, yogurt 
culture, Chr. Hansen's Laboratory, Milwaukee, WI, USA) was added at $0.75 \mathrm{~mL}$ per $3.78 \mathrm{~L}$ of mix for each bacterial strain, $7.56 \mathrm{~L}$ of mix per treatment was used. After mixing, the yogurt mixes were poured into previously labeled $340 \mathrm{~g}$ plastic cups.

The inoculated mixes were incubated at $40^{\circ} \mathrm{C}$ until $\mathrm{pH}$ reached $4.65 \pm 0.1$ to obtain a set-type yogurt and transferred to the cooler at $4^{\circ} \mathrm{C}$ for refrigeration until further analyses. For the sensory evaluation blueberry flavored yogurt with the same lactose treatments $(0 \%, 1 \%, 3 \%$ and $5 \% \mathrm{w} / \mathrm{w}$ added lactose) were manufactured. The manufacture process was the same with the exception that $15 \%$ $\mathrm{w} / \mathrm{w}$ blueberry puree was incorporated after plain yogurt manufacture and refrigerated at $4^{\circ} \mathrm{C}$. Product manufacture was replicated 3 times.

\subsection{Lactose Content}

Lactose concentration of yogurts was determined using the Lactose/ D-Galactose determination kit [24]. Briefly, $1 \mathrm{~g}$ of sample was weighed into a $100 \mathrm{~mL}$ volumetric flask. Then $60 \mathrm{~mL}$ of distilled water was added and flasks were incubated for 15 minutes at $70^{\circ} \mathrm{C}$. Samples were shaken from time to time. For clarification, $5 \mathrm{~mL}$ of Carrez-I-solution (3.60 g potassium hexacyanoferrate (II), $5 \mathrm{~mL}$ of Carrez-II-solution $(7.20 \mathrm{~g}$ of zinc sulfate/100 mL) and $10 \mathrm{~mL}$ of $\mathrm{NaOH}(0.1 \mathrm{M})$ were added and mixed after each addition. The sample solution was adjusted to $20^{\circ} \mathrm{C}-25^{\circ} \mathrm{C}$ and filled up to $100 \mathrm{~mL}$ with distilled water, then filtered using a $12.5 \mathrm{~cm}$ Whatman ${ }^{\oplus}$ filter paper. The clear solution was used for the assay. Absorbance measurements were taken at a wavelength of $340 \mathrm{~nm}$ using an Evolution 100 spectrophotometer (Thermo Scientific, Waltham, Massachusetts). Lactose concentrations were measured every 7 th day over the 35 days of storage for each of the 3 replications.

\section{3. $\mathrm{pH}$}

The $\mathrm{pH}$ of the yogurts was determined using the Oysters Series $\mathrm{pH}$ meter (Extech Instruments, Waltham, MA). The instrument was calibrated using commercial pH 4.00 and 7.00 buffers (Fisher Scientific, Fair Lawn, NJ) and instrument's temperature was adjusted to the sample's temperature of $8^{\circ} \mathrm{C} \pm 2^{\circ} \mathrm{C}$ before reading. Two measurements were taken per replication for each of the 3 replications.

\subsection{Titratable Acidity}

The titratable acidity (TA) was determined by weighing $9 \mathrm{~g}$ of yogurt to which 5 drops of phenolphthalein indicator solution were added. Samples were titrated with $0.1 \mathrm{~N} \mathrm{NaOH}$ as until color changed to rose pink that persisted for 30 seconds.

\subsection{Apparent Viscosity}

Apparent viscosities were measured using a Brookfield DV II + viscometer (Brookfield Engineering Lab Inc., Stoughton, MA, USA) with a helipath stand at 
$10^{\circ} \mathrm{C} \pm 2{ }^{\circ} \mathrm{C}$. A T bar B spindle was set to $10 \mathrm{rpm}$ to obtain a torque between $10 \%$ $90 \%$. The $\mathrm{T}$ bar B spindle was inserted in the sample at a constant depth of $2 \mathrm{~cm}$ from the top level of the sample container. The helipath was set in downward motion to cut new circular layers at increasing depths of the sample. Sample's container geometry was $4.55^{\prime \prime}$ top diameter, 3.25 " bottom diameter and 2.45" height with $340 \mathrm{~g}$ capacity. The data were gathered using the Wingather ${ }^{\circledast}$ software (Brookfield Engineering Lab Inc., Stoughton, MA, USA). The viscosity measurements were continuous over 33 seconds required to collect one hundred data points averaged per sample per replication.

\subsection{Syneresis}

Syneresis was determined with the method described by [13] with slight modifications. The $300 \mathrm{~mL}$ of yogurt mix was poured into plastic cups prior to incubation during yogurt manufacture. The cups of set yogurt were kept at an angle of $45^{\circ}$ and spontaneous whey was collected at the side of the cup with a pipette. Amount of whey in $\mathrm{mL}$ was measured at $22^{\circ} \mathrm{C}$. The yogurt gel was allowed to stand for 1 minute and any further surface whey was pipetted and total whey release in $\mathrm{mL}$ was measured.

\subsection{Growth}

Growths of Lactobacillus delbrueckii ssp. bulgaricus (LB-12) and Streptococcus thermophilus (ST-M5) were determined using the pour plate technique with serial dilutions of yogurt samples. Yogurts were sampled at days 1, 7, 14, 21, 28 and 35 of storage period. The yogurt in the cup was agitated and $1 \mathrm{~g}$ of yogurt was pipetted from the center of the cup into a sterile bottle containing $99 \mathrm{~mL}$ of sterile $0.1 \%$ peptone water (Difco, Detroit, MI, USA). Contents in bottle were agitated to prepare serial dilutions and plated on 5.2 modified $\mathrm{pH}$ Lactobacilli MRS agar for Lactobacillus bulgaricus LB-12 and Streptococcus thermophilus agar for Streptococcus thermophilus ST-M5. Pour plates were incubated anaerobically at $43^{\circ} \mathrm{C}$ for 72 hours for Lactobacillus bulgaricus LB-12 [25] and aerobically at $37^{\circ} \mathrm{C}$ for 24 hours for Streptococcus thermophilus ST-M5 [26] and colonies were counted.

\subsection{Coliform Counts}

The blueberry yogurt was tested for coliforms using petrifilms (3M $\mathrm{M}^{\oplus}$, St. Paul, $\mathrm{MN}$ ) which contain violet red bile agar (VRBA). The procedure was performed by weighing $11 \mathrm{~g}$ of yogurt samples in $99 \mathrm{~mL}$ of sterile $0.1 \%$ peptone water (Difco, Detroit, MI, USA). Contents in bottle were agitated and serial dilutions were prepared. Aliquots of $1 \mathrm{~mL}$ were taken from dilutions 10-1 and plated in duplicate for control and added lactose samples. Previously labeled petrifilms were incubated aerobically at $32^{\circ} \mathrm{C}$ for 24 hours.

\subsection{Sensory Study}

The sensory study was approved by the LSU Institutional Review Board with the 
IRB exemption number of HE13-6. Blueberry yogurt containing the four treatments $(0 \%, 1 \%, 3 \%$ and $5 \% \mathrm{w} / \mathrm{w}$ added lactose) was poured into $2.5 \mathrm{oz}$. previously labeled shuffle cups. A 3-digits random number code was used to label the cups. Consumer acceptance study was performed with 100 consumers of yogurt. One cup per treatment, that is four cups in total, was given to each consumer along with the evaluation questionnaire which consisted of a 9-points rating scale ( 1 = Dislike extremely, $9=$ Like extremely), with acceptability and purchase intent questions (yes/no). Panelists were asked to evaluate each yogurt sample for the following attributes: Appearance, Color, Aroma, Taste, Sourness, Sweetness, Thickness, Graininess and Overall like.

\subsection{Statistical Analysis}

The Lactobacillus bulgaricus LB-12 and Streptococcus thermophilus ST-M5 counts were converted to log 10 scale before analyzing the data by SAS. Data were analyzed using Proc Mixed of the SAS ${ }^{\circledR} 9.3$ program. Differences of Least Square Means were used to determine significant differences at $\mathrm{P}<0.05$ for main effects (lactose concentration and time) and interaction effects (lactose concentration ${ }^{\star}$ time). Sensory data are presented as mean \pm standard deviation (SD) of the means. Significant differences between means were analyzed at $\alpha=$ 0.05 using Tukey adjustment to determine the best treatment. All experiments were replicated three times.

\section{Results and Discussion}

\subsection{Lactose Content}

Lactose content of yogurts as influenced by lactose addition over storage of 35 days is shown in Figure 1. Treatment ${ }^{\star}$ day interaction effect was not significant

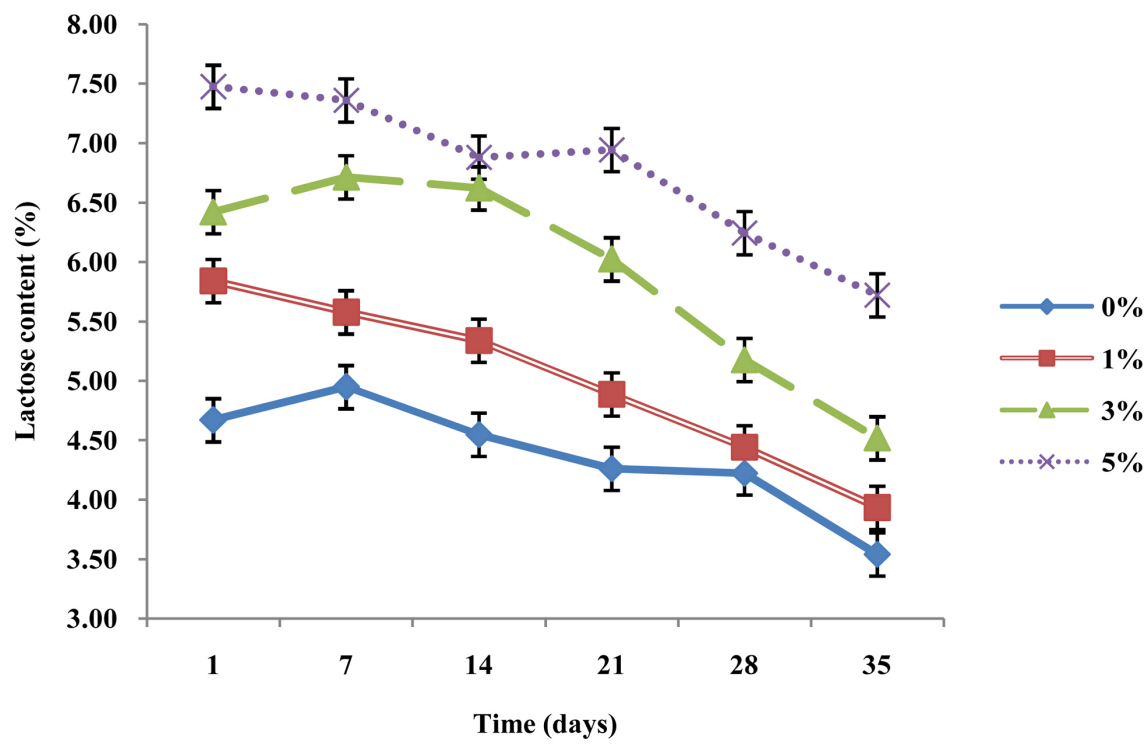

Figure 1. Lactose content of yogurts as influenced by lactose addition over storage period of 35 days, means $+\mathrm{SE}$. 
$(\mathrm{P}>0.05)$ while treatment effect and day effect were significant $(\mathrm{P}<0.05)$ (Table 1). Lactose content decreased for all treatments over time (Figure 1). Yogurts with lactose added at $1 \%, 3 \%, 5 \%$ stayed in that proportion higher than control throughout the 35 days of storage (Figure 1).

As expected, treatment containing $5 \% \mathrm{w} / \mathrm{w}$ added lactose had the highest lactose content (Table 2). The highest lactose content was observed at days 1 and 7 of storage period (Table 3). Also, as expected lactose content steadily decreases from day 21 onwards over the rest of the storage time (Table 3). Reference [27] found a reduction in lactose concentration of yogurt after storage period of 7 days. They attributed the loss of lactose to the fact that lactic acid bacteria not only produce lactic acid from lactose but also flavor compounds and polysaccharides during storage consuming more of this molecule.

Table 1. Probability $>$ F Value $(\mathrm{Pr}>\mathrm{F}$ ) for lactose content (LC), $\mathrm{pH}$, titratable acidity (TA), apparent viscosity (AV), syneresis, Streptococcus thermophilus ST-M5 counts (ST) and Lactobacillus delbrueckii ssp. bulgaricus LB-12 counts (LB) in yogurts containing $0 \%$, $1 \%, 3 \%$ and $5 \% \mathrm{w} / \mathrm{w}$ of added lactose over storage period of 35 days.

\begin{tabular}{cccccccc}
\hline Effect & LC & pH & TA & AV & Syneresis & ST & LB \\
\hline Treatment & $<0.0001$ & 0.0003 & $<0.0001$ & $<0.0001$ & $<0.0001$ & 0.0225 & 0.5903 \\
Day & $<0.0001$ & $<0.0001$ & $<0.0001$ & 0.6735 & $<0.0001$ & $<0.0001$ & $<0.0001$ \\
Treatment ${ }^{\star}$ Day & 0.0970 & 0.9988 & $<0.0001$ & 0.8809 & $<0.0001$ & 0.0859 & 0.1000 \\
\hline
\end{tabular}

Table 2. Least square means for lactose content of yogurts as influenced by added lactose concentrations.

\begin{tabular}{cc}
\hline Added lactose concentration (\%) & Lactose content \\
\cline { 2 - 2 } Control (0) & LS means \\
\hline One & $4.37^{\mathrm{d}}$ \\
Three & $5.01^{\mathrm{c}}$ \\
Five & $5.92^{\mathrm{b}}$ \\
\hline
\end{tabular}

${ }^{a-d}$ LS means with the same letter does not indicate significant difference $(\mathrm{P}<0.05)$.

Table 3. Least square means for lactose content of yogurts as influenced by the storage period of 35 days.

\begin{tabular}{cc}
\hline & Lactose content \\
\cline { 2 - 2 } Storage period (days) & LS means \\
\hline 1 & $6.11^{\mathrm{a}}$ \\
7 & $6.16^{\mathrm{a}}$ \\
21 & $5.85^{\mathrm{ab}}$ \\
28 & $5.53^{\mathrm{b}}$ \\
35 & $5.03^{\mathrm{c}}$ \\
\hline
\end{tabular}

${ }^{\text {a-d } L S}$ means with the same letter does not indicate significant difference $(\mathrm{P}<0.05)$. 


\section{2. $\mathrm{pH}$}

The $\mathrm{pH}$ of yogurts as influenced by added lactose concentration over storage of 35 days is shown in Figure 2. Treatment ${ }^{\star}$ day interaction effect was not significant $(\mathrm{P}>0.05)$ while treatment effect and day effect were significant $(\mathrm{P}<0.05)$ (Table 1). The $\mathrm{pH}$ values decreased for all treatments at day 35 compared to day 1 (Figure 2). According to [28] a decrease in $\mathrm{pH}$ during storage is expected as a result of the metabolic activity of starter cultures. Yogurts containing $5 \% \mathrm{w} / \mathrm{w}$ added lactose had the lowest $\mathrm{pH}$ (Table 4). The more lactose present, the higher the production of lactic acid by the starter cultures. According to [29] at high $\mathrm{pH}$ most of the lactic acid is formed due to a growth-associated mechanism and the growth curve has a short stationary growth phase. On the contrary, at low $\mathrm{pH}$ most of the lactic acid produced is non-growth-associated [29]. The lowest $\mathrm{pH}$ values were obtained from day 14 onwards (Table 5).

\subsection{Titratable Acidity}

The TA of yogurts as influenced by added lactose concentration over storage of

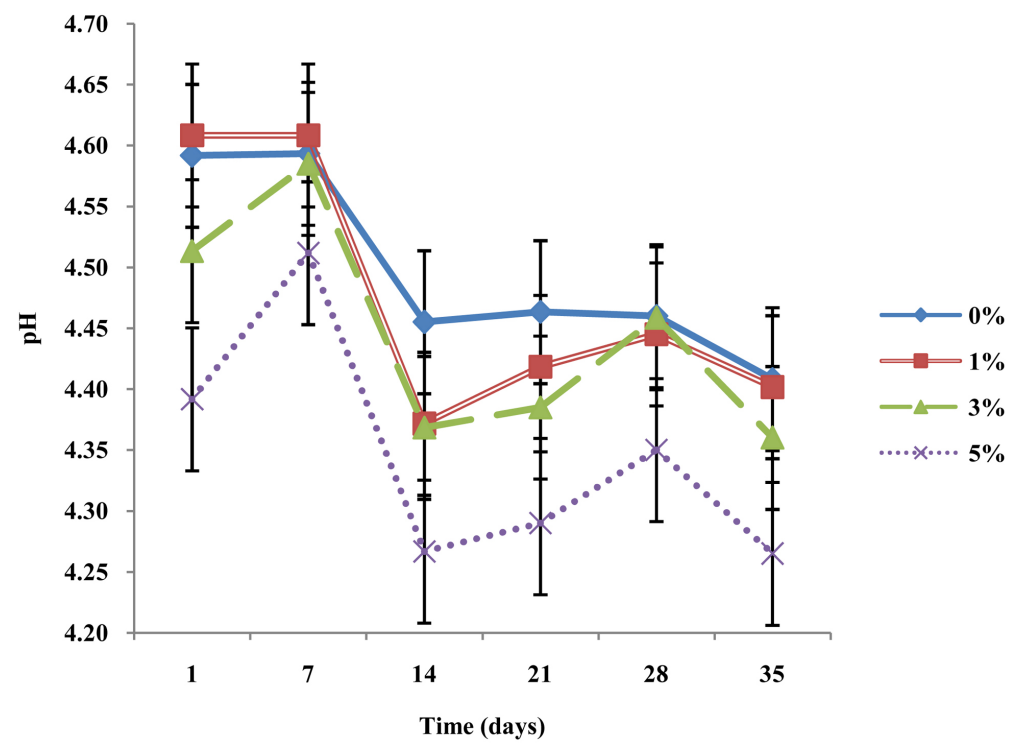

Figure 2. $\mathrm{pH}$ of yogurts as influenced by added lactose levels over storage period of 35 days, means + SE.

Table 4. Least square means for $\mathrm{pH}$ of yogurts as influenced by added lactose concentrations.

\begin{tabular}{cc}
\hline Added lactose concentration (\%) & $\mathrm{pH}$ \\
\cline { 2 - 2 } Control (0) & LS means \\
One & $4.50^{\mathrm{a}}$ \\
Three & $4.48^{\mathrm{a}}$ \\
Five & $4.45^{\mathrm{a}}$ \\
\hline
\end{tabular}

\footnotetext{
${ }^{a-b} L S$ means with the same letter does not indicate significant difference $(\mathrm{P}<0.05)$.
} 
Table 5. Least square means for $\mathrm{pH}$ of yogurts as influenced by the storage period of 35 days.

\begin{tabular}{|c|c|}
\hline \multirow{2}{*}{ Storage period (days) } & $\mathrm{pH}$ \\
\hline & LS means \\
\hline 1 & $4.53^{\mathrm{ab}}$ \\
\hline 7 & $4.58^{\mathrm{a}}$ \\
\hline 14 & $4.37^{\mathrm{c}}$ \\
\hline 21 & $4.39^{c}$ \\
\hline 28 & $4.43^{\mathrm{bc}}$ \\
\hline 35 & $4.36^{\mathrm{c}}$ \\
\hline
\end{tabular}

${ }^{a-c}$ LS means with the same letter does not indicate significant difference $(\mathrm{P}<0.05)$.

35 days is shown in Figure 3. Treatment ${ }^{\star}$ day interaction effect, treatment effect and day effect were significant $(\mathrm{P}<0.05)$ (Table 1$)$.

In general, yogurts containing $1 \%$ and $3 \% \mathrm{w} / \mathrm{w}$ lactose had higher TA at day 35 compared to days 1 and 7 (Table 6, Figure 3). Yogurts with 3\% and 5\% w/w added lactose had lower TA values compared to $0 \%$ and $1 \% \mathrm{w} / \mathrm{w}$ added lactose, except at day 7 for $3 \% \mathrm{w} / \mathrm{w}$ added lactose (Table 6). This phenomenon can be explained through the fact that whey separation caused by lactose hydrolysis leads to slow rate of acid production in yogurt [30]. As lactose is hydrolyzed by lactic acid bacteria the amount of lactic acid production increased. This behavior may be due to the availability of more quantity of easily fermentable sugar (glucose) which is required for the faster growth of starters [31] [32] [33]. Reference [34] reported that changes in titratable acidity do not necessarily have an effect on $\mathrm{pH}$ values.

\subsection{Apparent Viscosity}

The apparent viscosity of yogurts as influenced by lactose addition over storage of 35 days is shown in Figure 4. Treatment ${ }^{\star}$ day interaction effect and day effect were not significant $(P>0.05)$ while treatment effect was significant $(P<0.05)$ (Table 1). Yogurts containing 5\% w/w added lactose had the lowest apparent viscosity values compared to $0 \%, 1 \%$ and $3 \% \mathrm{w} / \mathrm{w}$ added lactose (Table 7 ). This was because of the higher amount of whey released. Weaker body and texture of yogurt may be due to higher amount of whey separation which reduced the viscosity when lactose is hydrolyzed [35] [36] [37].

\subsection{Syneresis}

The syneresis of yogurts as influenced by lactose addition over storage of 35 days is shown in Figure 5. Treatment ${ }^{\star}$ day interaction effect, treatment effect and day effect were significant $(\mathrm{P}<0.05)$ (Table 1$)$. Yogurts containing 5\% w/w added lactose had significantly the highest syneresis values compared to $0 \%, 1 \%$ and $3 \% \mathrm{w} / \mathrm{w}$ added lactose during storage period at day 7 and from day 21 onwards (Table 8). Reference [30] reported that as the degree of lactose hydrolysis in- 


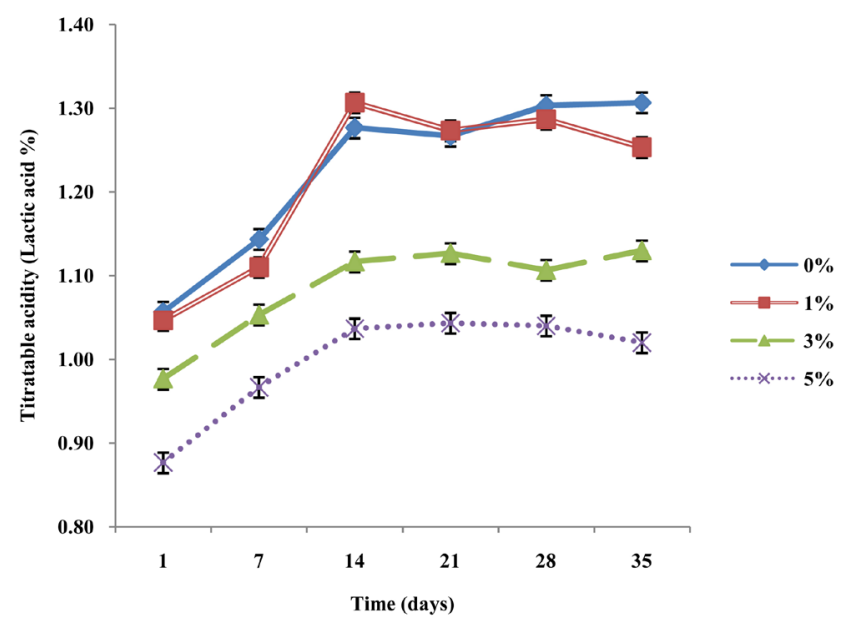

Figure 3. Titratable acidity of yogurts as influenced by added lactose levels over storage period of 35 days, means + SE.

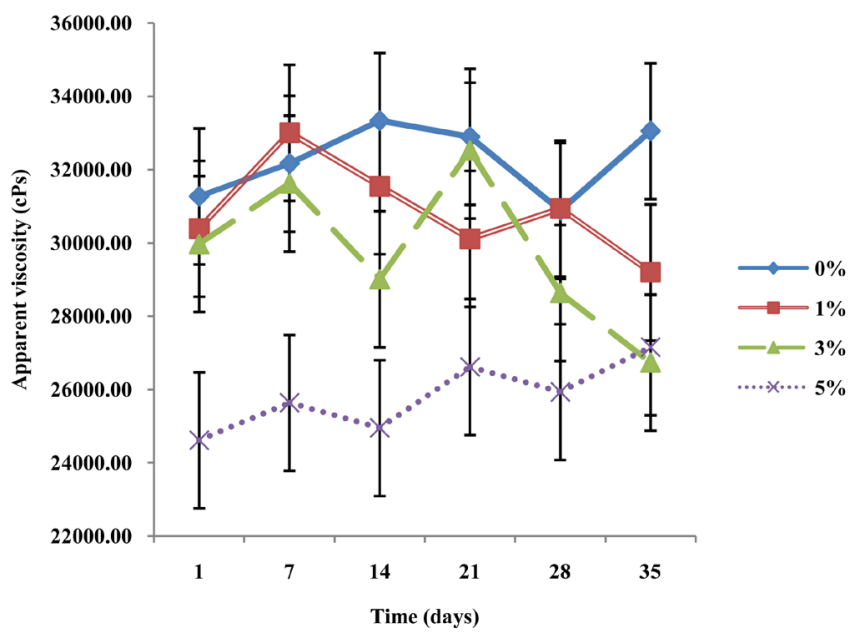

Figure 4. Apparent viscosity of yogurts as influenced by added lactose levels over storage period of 35 days, means + SE.

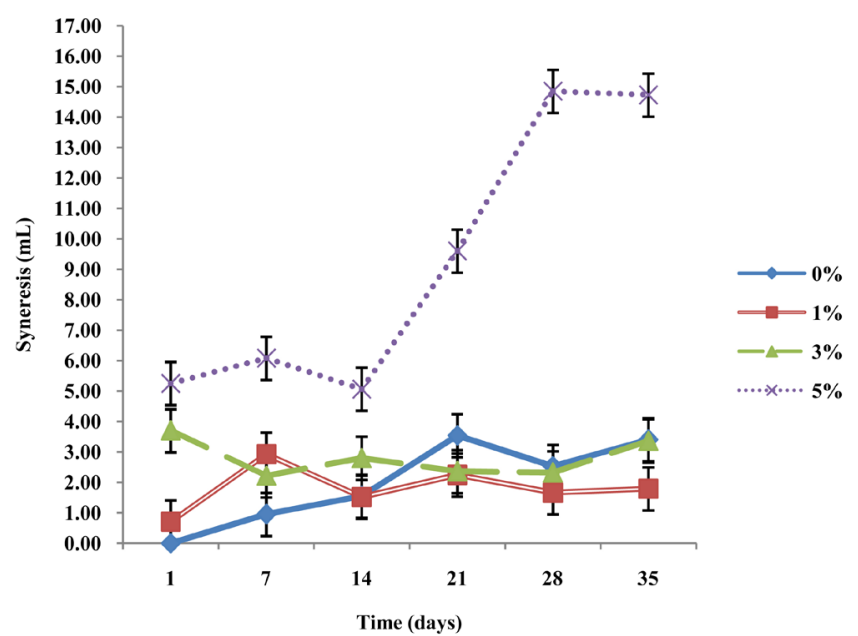

Figure 5. Syneresis of yogurts as influenced by added lactose levels over storage period of 35 days, means + SE. 
Table 6. Least square means for titratable acidity of yogurts as influenced by added lactose concentrations over storage period of 35 days.

\begin{tabular}{ccccccc}
\hline \multirow{2}{*}{$\begin{array}{c}\text { Added lactose concentration } \\
(\%)\end{array}$} & \multicolumn{5}{c}{ Titratable acidity } \\
\cline { 2 - 7 } & 1 & 7 & 14 & 21 & 28 & 35 \\
\cline { 2 - 7 } & $1.06^{\mathrm{CDEF}}$ & $1.14^{\mathrm{B}}$ & $1.28^{\mathrm{A}}$ & $1.27^{\mathrm{A}}$ & $1.30^{\mathrm{A}}$ & $1.31^{\mathrm{A}}$ \\
Control (0) & $1.05^{\mathrm{DEF}}$ & $1.11^{\mathrm{BCD}}$ & $1.31^{\mathrm{A}}$ & $1.27^{\mathrm{A}}$ & $1.29^{\mathrm{A}}$ & $1.25^{\mathrm{A}}$ \\
One & $0.98^{\mathrm{GH}}$ & $1.05^{\mathrm{CDEF}}$ & $1.12^{\mathrm{BC}}$ & $1.13^{\mathrm{B}}$ & $1.11^{\mathrm{BCDE}}$ & $1.13^{\mathrm{B}}$ \\
Three & $0.88^{\mathrm{I}}$ & $0.97^{\mathrm{H}}$ & $1.04^{\mathrm{FG}}$ & $1.04^{\mathrm{DEFG}}$ & $1.04^{\mathrm{EFG}}$ & $1.02^{\mathrm{FGH}}$ \\
Five & &
\end{tabular}

Table 7. Least square means for apparent viscosity of yogurts as influenced by added lactose concentrations.

\begin{tabular}{cc}
\hline \multirow{2}{*}{ Added lactose concentration (\%) } & Apparent viscosity \\
\cline { 2 - 2 } Control $(0)$ & LS means \\
One & $32,267.00^{\mathrm{a}}$ \\
Three & $30,866.00^{\mathrm{a}}$ \\
Five & $29,751.00^{\mathrm{a}}$ \\
\hline
\end{tabular}

${ }^{\mathrm{a}-\mathrm{b}} \mathrm{LS}$ means with the same letter does not indicate significant difference $(\mathrm{P}<0.05)$.

Table 8. Least square means for syneresis of yogurts as influenced by added lactose concentrations over storage period of 35 days.

\begin{tabular}{ccccccc}
\hline & \multicolumn{6}{c}{ Syneresis } \\
\cline { 2 - 7 } Added lactose concentration (\%) & \multicolumn{5}{c}{ Time (days) } \\
\cline { 2 - 7 } & 1 & 7 & 14 & 21 & 28 & 35 \\
\hline Control (0) & $0.00^{\mathrm{E}}$ & $0.95^{\mathrm{E}}$ & $1.54^{\mathrm{DE}}$ & $3.54^{\mathrm{CDE}}$ & $2.53^{\mathrm{CDE}}$ & $3.40^{\mathrm{CDE}}$ \\
One & $0.70^{\mathrm{E}}$ & $2.93^{\mathrm{CDE}}$ & $1.52^{\mathrm{DE}}$ & $2.24^{\mathrm{CDE}}$ & $1.66^{\mathrm{DE}}$ & $1.79^{\mathrm{DE}}$ \\
Three & $3.70^{\mathrm{CDE}}$ & $2.22^{\mathrm{DE}}$ & $2.80^{\mathrm{CDE}}$ & $2.36^{\mathrm{CDE}}$ & $2.32^{\mathrm{CDE}}$ & $3.36^{\mathrm{CDE}}$ \\
Five & $5.25^{\mathrm{CD}}$ & $6.08^{\mathrm{BC}}$ & $5.06^{\mathrm{CD}}$ & $9.60^{\mathrm{B}}$ & $14.85^{\mathrm{A}}$ & $14.73^{\mathrm{A}}$ \\
\hline
\end{tabular}

${ }^{A B C D E}$ LS means with the same letter does not indicate significant difference $(\mathrm{P}<0.05)$.

creased the amount of whey separation increased $(\mathrm{P}<0.05)$.

\subsection{Growth}

\subsubsection{Streptococcus thermophilus ST-M5}

The growth of Streptococcus thermophilus ST-M5 as influenced by added lactose concentration over storage of 35 days is shown in Figure 6. Treatment ${ }^{*}$ day interaction effect was not significant $(P>0.05)$ while the treatment effect and day effect were significant $(\mathrm{P}<0.05)$ (Table 1$)$. In general, upon addition of lactose there was an increase in viable counts at day 35 compared to day 1 (Figure 6). Reference [38] found that the counts of $S$. thermophilus and $L$. bulgaricus decreased after $12 \mathrm{~h}$ of storage due to a reduction of lactose content in 


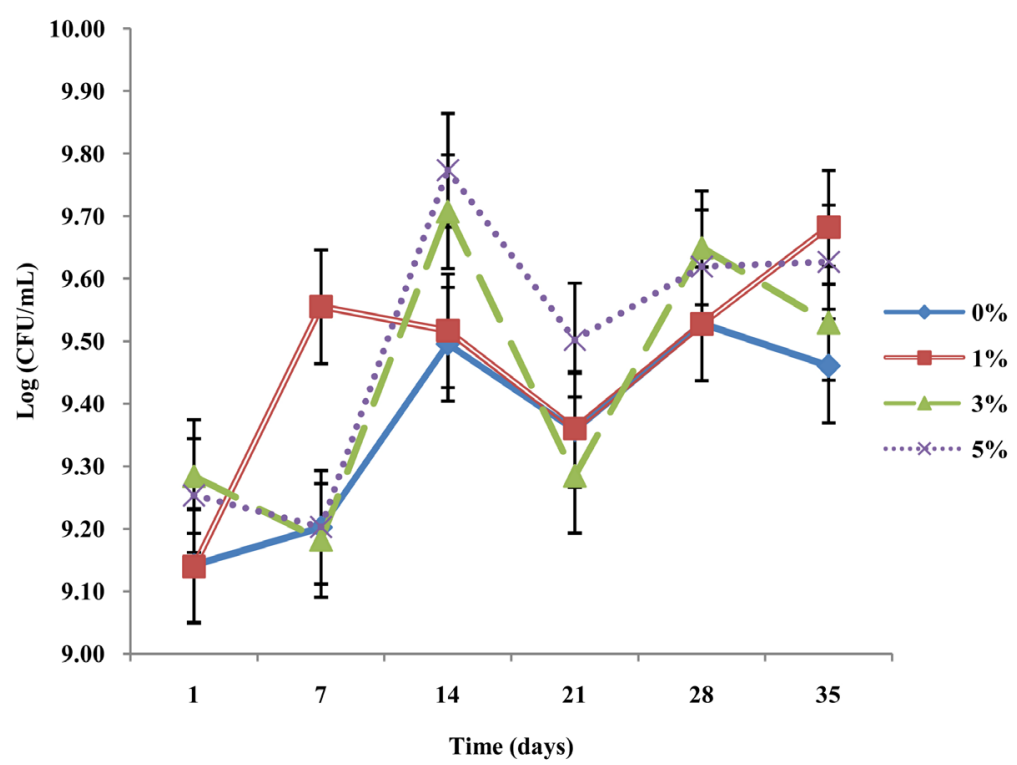

Figure 6. Growth of Streptococcus thermophilus ST-M5 as influenced by added lactose concentration over storage period of 35 days, means + SE.

yogurt. Use of $5 \% \mathrm{w} / \mathrm{w}$ added lactose resulted in significant higher counts compared to control (Table 9). Reference [39] studied the effect of $2 \%$ lactose on probiotic bacteria in soymilk. Counts of soymilk containing lactose were significantly higher than soymilk with the absence of lactose $(8.13 \log \mathrm{CFU} / \mathrm{mL}$ and $6.36 \log \mathrm{CFU} / \mathrm{mL}$ respectively). They stated that probiotic bacteria are traditionally grown in lactose rich dairy foods such as yogurt; hence the growth is better in the presence of this carbohydrate. The highest counts of Streptococcus thermophilus ST-M5 were observed at days 14 and 28 of storage (Table 10). At day 21 , there was a significant decrease in counts compared to days 14 and 28 (Table 10). However, the counts stayed within the same log CFU/mL (Figure 6). Studies have shown that Streptococcus thermophilus survive well in yogurt throughout the shelf life [40] [41] [42]. Mean log difference in the viable counts of Streptococcus thermophilus ST-M5 was obtained by subtracting log CFU/mL of day 1 from day 35 of storage. A high number indicates higher bacterial growth. The bacteria survival was higher for lactose added samples compared to control. The bacterial survival was the highest for $1 \% \mathrm{w} / \mathrm{w}$ added lactose compared to the rest (Table 11).

\subsubsection{Lactobacillus delbrueckii ssp. bulgaricus LB-12}

The growth characteristics of Lactobacillus bulgaricus LB-12 as influenced by added lactose concentration over storage of 35 days is shown in Figure 7. Treatment ${ }^{\star}$ day interaction effect and treatment effect were not significant $(\mathrm{P}>$ 0.05). The day effect was significant $(\mathrm{P}<0.05)$ (Table 1). Viable counts of Lactobacillus bulgaricus LB-12 decreased for all treatments over storage period (Figure 7). This behavior agrees with the results reported by [29] who found that when fermentations were carried out with $60 \mathrm{~g} /$ liter of lactose in the medium, specific growth rates for Lactobacillus delbrueckii ssp. bulgaricus increased 
Table 9. Least square means ( $\log \mathrm{CFU} / \mathrm{mL}$ ) for growth of Streptococcus thermophilus ST-M5 as influenced by added lactose concentrations.

\begin{tabular}{cc}
\hline \multirow{2}{*}{ Added lactose concentration (\%) } & Streptococcus thermophilus ST-M5 \\
\cline { 2 - 2 } & LS means \\
\hline Control (0) & $9.33^{\mathrm{b}}$ \\
One & $9.46^{\mathrm{ab}}$ \\
Three & $9.44^{\mathrm{ab}}$ \\
Five & $9.49^{\mathrm{a}}$ \\
\hline
\end{tabular}

${ }^{a-b}$ LS means with the same letter does not indicate significant difference $(P<0.05)$.

Table 10. Least square means (Log CFU/mL) for growth of Streptococcus thermophilus ST-M5 and Lactobacillus bulgaricus LB-12 as influenced by the storage period of 35 days.

\begin{tabular}{|c|c|c|}
\hline \multirow{2}{*}{ Storage period (days) } & Streptococcus thermophilus ST-M5 & Lactobacillus bulgaricus LB-12 \\
\hline & \multicolumn{2}{|c|}{ LS means } \\
\hline 1 & $9.20^{c}$ & $8.38^{\mathrm{a}}$ \\
\hline 7 & $9.28^{\mathrm{c}}$ & $8.19^{\mathrm{bc}}$ \\
\hline 14 & $9.62^{\mathrm{a}}$ & $8.38^{\mathrm{a}}$ \\
\hline 21 & $9.38^{\mathrm{bc}}$ & $8.18^{\mathrm{c}}$ \\
\hline 28 & $9.58^{\mathrm{a}}$ & $7.21^{\mathrm{d}}$ \\
\hline 35 & $9.53^{\mathrm{ab}}$ & $6.34^{\mathrm{e}}$ \\
\hline
\end{tabular}

${ }^{\text {a-d } L S}$ means with the same letter does not indicate significant difference $(\mathrm{P}<0.05)$.

Table 11. Mean log difference in the viable counts of Streptococcus thermophilus ST-M5 and Lactobacillus bulgaricus LB-12 as influenced by added lactose concentration.

\begin{tabular}{ccc}
\hline \multirow{2}{*}{$\begin{array}{c}\text { Added lactose concentration } \\
(\%)\end{array}$} & $\begin{array}{c}\text { Streptococcus thermophilus } \\
\text { ST-M5 }\end{array}$ & $\begin{array}{c}\text { Lactobacillus bulgaricus } \\
\text { LB-12 }\end{array}$ \\
\cline { 2 - 3 } & \multicolumn{2}{c}{ Log CFU/mL } \\
\hline Control (0) & 0.15 & 1.65 \\
One & 0.54 & 2.31 \\
Three & 0.25 & 2.11 \\
Five & 0.38 & 2.09 \\
\hline
\end{tabular}

to a maximum and then decreased. Reference [43] reported that the growth of Lactobacillus delbrueckii ssp. bulgaricus declined from 7 to 6 log CFU/g in yogurt during storage period of 28 days. These findings might also be explained by the competitive and growth advantage that $S$. thermophilus shows over $L$. bulgaricus [44] [45]. The highest counts of Lactobacillus bulgaricus LB-12 were observed at days 1 and 14 of storage (Table 10). Mean log difference in the viable counts of Lactobacillus bulgaricus LB-12 was obtained by subtracting log $\mathrm{CFU} / \mathrm{mL}$ of day 35 from day 1 of storage. A low number indicates less bacterial death. The bacterial death was the lowest for control compared to the rest (Table $11)$. 


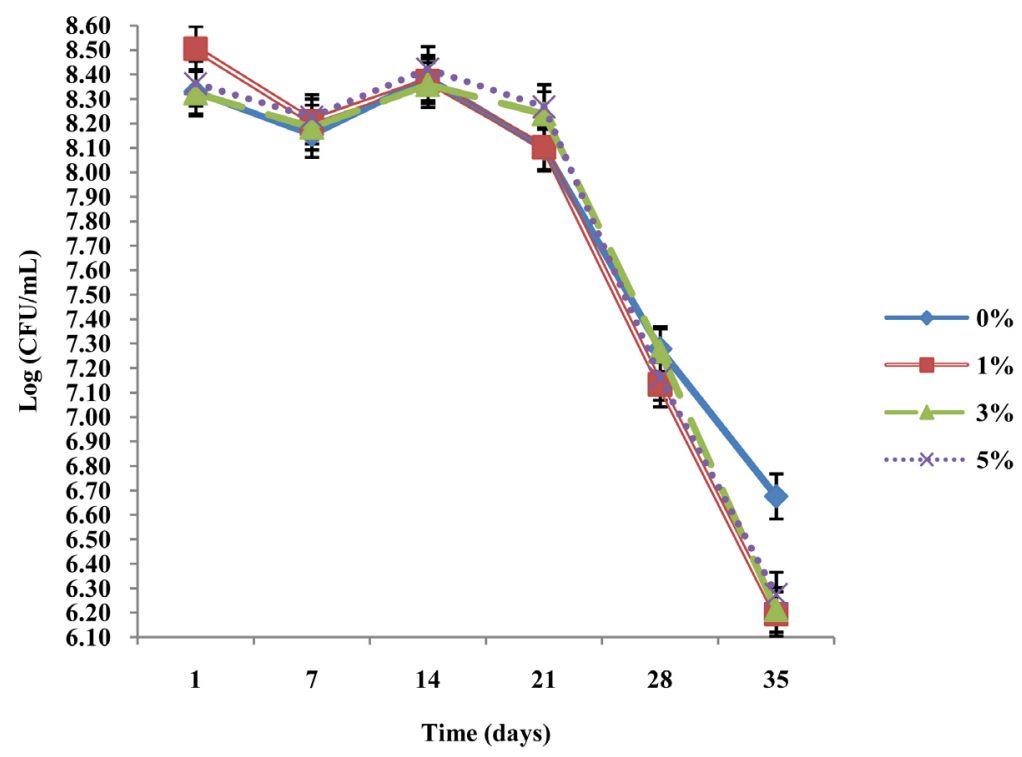

Figure 7. Growth of Lactobacillus bulgaricus LB-12 as influenced by added lactose concentration over storage period of 35 days. means + SE.

\subsection{Coliform Counts}

There were no detectable coliforms in all samples.

\subsection{Sensory Study}

Means for all tested attributes (appearance, color, aroma, taste, sourness, sweetness, thickness, graininess, and overall liking) are shown in Figure 8. The probabilities for fixed effect of sensory attributes are shown in Table 12. Samples containing $1 \% \mathrm{w} / \mathrm{w}$ added lactose had higher scores for thickness compared to $5 \% \mathrm{w} / \mathrm{w}$ added lactose, which might be explained by increased syneresis in added lactose samples. Control samples had lower scores for graininess compared to $5 \% \mathrm{w} / \mathrm{w}$ added lactose (Table 13), possibly due to difference in total solids content.

The overall liking scores indicated that samples containing added lactose were preferred over control (Table 13). Lactose addition did not appear to significantly $(\mathrm{P}>0.05)$ impact appearance and color of yogurts (Table 12). Similar results were reported by [30] who studied lactose hydrolysis on enzymatically hydrolyzed yogurts. Aroma and taste are important sensory characteristics of yogurt [46]. Control had higher aroma scores compared to $1 \%$ and $3 \% \mathrm{w} / \mathrm{w}$ added lactose (Table 13). For taste, sourness and sweetness samples containing added lactose had higher scores than control (Table 13). Yogurt acceptability frequency values are shown in Figure 9(a). Added lactose yogurts had a greater acceptability compared to control yogurts. The consumer acceptability of yogurts increased as lactose addition increased. Yogurts containing 5\% w/w added lactose led to the highest acceptability (88\%) compared to control (70\%). This is probably due to a better palatability given by the sweetness of lactose. According to [30] when lactose is hydrolyzed in yogurt it resulted in increased digestibility, sweeter 


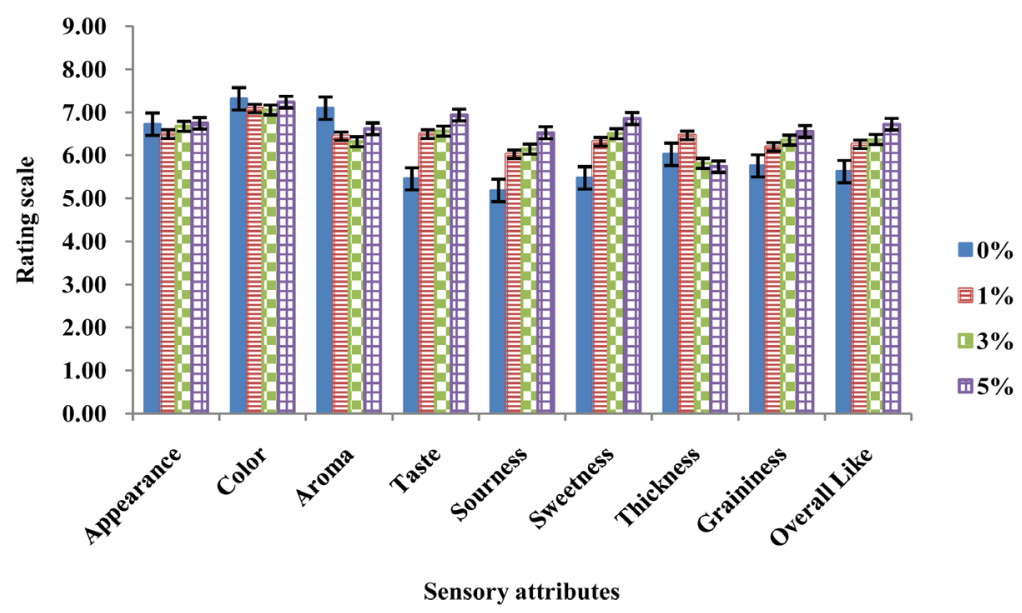

Figure 8. Means + SE for sensory attributes of blueberry yogurt as influenced by lactose addition.

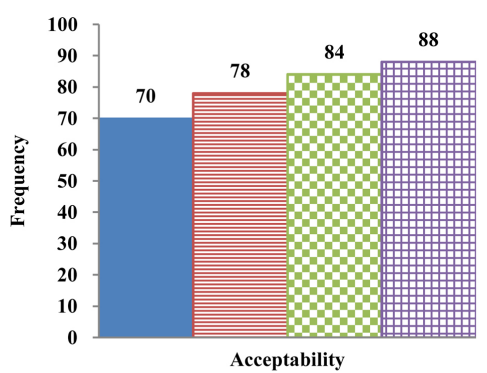

(a)

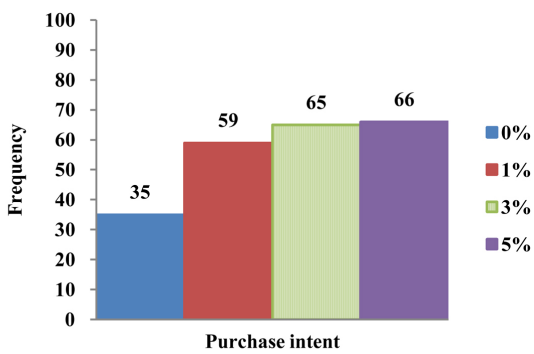

(b)

Figure 9. Frequency for (a) acceptability and (b) purchase intent of blueberry yogurt as influenced by lactose addition.

Table 12. Probability $>$ F Value $(\operatorname{Pr}>$ F) for fixed effect of sensory attributes of yogurts containing $0 \%, 1 \%, 3 \%$ and $5 \% \mathrm{w} / \mathrm{w}$ added lactose.

\begin{tabular}{cc}
\hline Sensory attributes & Treatment effect \\
\hline Appearance & 0.6258 \\
Color & 0.3587 \\
Aroma & 0.0011 \\
Taste & $<0.0001$ \\
Sourness & $<0.0001$ \\
Sweetness & $<0.0001$ \\
Thickness & 0.0217 \\
Graininess & 0.0095 \\
Overall Like & 0.0001
\end{tabular}

taste, and better mouth feel. Yogurt purchase intent frequency values are shown in Figure 9(b). Added lactose yogurts had greater purchase intent values compared to control yogurts. Purchase intent increased as lactose addition increased. Yogurts containing 5\% w/w added lactose led to higher purchase intent (66\%) compared to control (35\%). Reference [47] reported that sweetness is one of the 
Table 13. Means \pm SD for sensory properties of yogurts as influenced by added lactose concentrations.

\begin{tabular}{ccccc}
\hline \multirow{2}{*}{ Sensory attributes } & \multicolumn{4}{c}{ Added lactose concentration (\%) } \\
\cline { 2 - 5 } & Control (0) & One & Three & Five \\
\hline Appearance & $6.73^{\mathrm{a}} \pm 1.48$ & $6.50^{\mathrm{a}} \pm 1.56$ & $6.68^{\mathrm{a}} \pm 1.48$ & $6.75^{\mathrm{a}} \pm 1.43$ \\
Color & $7.32^{\mathrm{a}} \pm 1.14$ & $7.09^{\mathrm{a}} \pm 1.26$ & $7.06^{\mathrm{a}} \pm 1.14$ & $7.24^{\mathrm{a}} \pm 1.22$ \\
Aroma & $7.10^{\mathrm{a}} \pm 1.46$ & $6.45^{\mathrm{b}} \pm 1.40$ & $6.32^{\mathrm{b}} \pm 1.61$ & $6.62^{\mathrm{ab}} \pm 1.35$ \\
Taste & $5.46^{\mathrm{b}} \pm 1.93$ & $6.50^{\mathrm{a}} \pm 1.81$ & $6.57^{\mathrm{a}} \pm 1.55$ & $6.94^{\mathrm{a}} \pm 1.43$ \\
Sourness & $5.19^{\mathrm{b}} \pm 1.93$ & $6.03^{\mathrm{a}} \pm 1.70$ & $6.15^{\mathrm{a}} \pm 1.58$ & $6.53^{\mathrm{a}} \pm 1.61$ \\
Sweetness & $5.48^{\mathrm{b}} \pm 1.79$ & $6.32^{\mathrm{a}} \pm 1.63$ & $6.51^{\mathrm{a}} \pm 1.49$ & $6.86^{\mathrm{a}} \pm 1.33$ \\
Thickness & $6.03^{\mathrm{ab}} \pm 1.84$ & $6.47^{\mathrm{a}} \pm 1.71$ & $5.82^{\mathrm{ab}} \pm 1.84$ & $5.74^{\mathrm{b}} \pm 1.85$ \\
Graininess & $5.76^{\mathrm{b}} \pm 1.81$ & $6.20^{\mathrm{ab}} \pm 1.68$ & $6.36^{\mathrm{ab}} \pm 1.79$ & $6.56^{\mathrm{a}} \pm 1.63$ \\
Overall Like & $5.63^{\mathrm{b}} \pm 1.85$ & $6.26^{\mathrm{ab}} \pm 1.85$ & $6.37^{\mathrm{a}} \pm 1.70$ & $6.73^{\mathrm{a}} \pm 1.53$ \\
\hline
\end{tabular}

${ }^{\mathrm{a}-\mathrm{b}}$ Means with the same letter does not indicate significant difference $(\mathrm{P}<0.05)$.

main traits for flavored yogurts.

\section{Conclusion}

Results indicated that added lactose had a positive effect on yogurt characteristics. Growth of Streptococcus thermophilus ST-M5 was significantly increased by $5 \% \mathrm{w} / \mathrm{w}$ lactose addition in yogurt. Lactose addition did not have a significant effect on growth of Lactobacillus bulgaricus LB-12 in yogurt. Treatments containing $5 \% \mathrm{w} / \mathrm{w}$ added lactose showed the highest lactose content during storage period and the lowest $\mathrm{pH}$. Treatment containing $5 \%$ added lactose showed the lowest viscosity values compared to the remaining yogurts; and the highest syneresis values over storage period of 35 days. The amount of added lactose had no effect on appearance and color of blueberry yogurt. Scores for aroma were higher for control and 5\% w/w added lactose. Samples containing added lactose showed higher scores for taste, sourness and sweetness compared to control. Lactose addition contributed to higher scores for overall liking. The acceptability of yogurts and purchase intent frequency scores markedly increased with the addition of lactose.

\section{Acknowledgements}

This study was funded by Hatch funds. Support of LSU AgCenter is appreciated.

\section{Conflicts of Interest}

The authors declare no conflicts of interest regarding the publication of this paper.

\section{References}

[1] CFR (Code of Federal Regulations, United States) (2017) 21 CFR 131.200. https://www.accessdata.fda.gov/scripts/cdrh/cfdocs/cfcfr/CFRSearch.cfm?fr=131.20 
0\&SearchTerm=yogurt

[2] Trachoo, N. (2002) Yogurt: The Fermented Milk. Songklanakarin Journal of Science and Technology, 24, 726-736.

[3] Linares, D.M., O’Callaghan, T.F., O’Connor, P.M., Ross, R.P. and Stanton, C. (2016) Streptococcus thermophilus APC151 Strain Is Suitable for the Manufacture of Naturally GABA-Enriched Bioactive Yogurt. Frontiers in Microbiology, 7, 1876. https://doi.org/10.3389/fmicb.2016.01876

[4] Minard, R. (1990) Introduction to Organic Laboratory Techniques: A Microscale Approach. Pavia, Lampman, Kriz \& Engel, Saunders. Penn State Univ.

[5] Huppertz, T. (2017) Lactose in Yogurt. In: Shah, N.P., Ed., Yogurt in Health and Disease Prevention, Academic Press, Cambridge, Chapter 22, 387-394. https://doi.org/10.1016/B978-0-12-805134-4.00022-5

[6] Lee, W.J. and Lucey, J.A. (2010) Formation and Physical Properties of Yogurt. Asian-Australian Journal of Animal Science, 23, 1127-1136.

https://doi.org/10.5713/ajas.2010.r.05

[7] Christensen, V.W. (1970) Yogurt. The Bright Star among Dairy Products. Food Product Development, 4, 18.

[8] De Vos, W.M. and Vaughan, E.E. (1994) Genetics of Lactose Utilization in Lactic Acid Bacteria. FEMS Microbiology Reviews, 15, 217-237.

https://doi.org/10.1111/j.1574-6976.1994.tb00136.x

[9] Guo, C., Xin, L., Dong, Y., Zhang, X., Wang, X., Fu, H. and Wang, Y. (2018) Dielectric Properties of Yogurt for Online Monitoring of Fermentation Process. Food and Bioprocess Technology, 11, 1096-1100. https://doi.org/10.1007/s11947-018-2072-y

[10] Hervert, C.J., Martin, N.H., Boor, K.J. and Wiedmann, M. (2017) Survival and Detection of Coliforms, Enterobacteriaceae, and Gram-Negative Bacteria in Greek Yogurt. Journal of Dairy Science, 100, 950-960. https://doi.org/10.3168/jds.2016-11553

[11] Tramer, J. (1973) Yogurt Cultures. International Journal of Dairy Technology, 26, 16-21. https://doi.org/10.1111/j.1471-0307.1973.tb02053.x

[12] Tyl, C. and Sadler, G.D. (2017) pH and Titratable Acidity. In: Food Analysis, Springer, Cham, 389-406. https://doi.org/10.1007/978-3-319-45776-5_22

[13] Amatayakul, T., Sherkat, F. and Shah, N.P. (2006) Syneresis in Set Yogurt as Affected by EPS Starter Cultures and Levels of Solids. International Journal of Dairy Technology, 59, 216-221. https://doi.org/10.1111/j.1471-0307.2006.00264.x

[14] Tamime, A.Y. and Deeth, H.C. (1980) Yogurt: Technology and Biochemistry. Journal of Food Protection, 43, 939-977. https://doi.org/10.4315/0362-028X-43.12.939

[15] Shah, N.P. (2003) Yogurt: The Product and Its Manufacture. In: Caballero, B., Trugo, L.C. and Finglas, P.M., Eds., Encyclopedia of Food Science and Nutrition, Vol. 10, 2nd Edition, Academic Press, London, 6252-6259. https://doi.org/10.1016/B0-12-227055-X/01305-5

[16] Rasic, J.L. and Kurmann, J.A. (1978) Yoghurt: Scientific Grounds, Technology, Manufacture and Preparation. Technical Dairy Publishing House, Berne.

[17] Tamime, A.Y. and Robinson, R.K. (1985) Yoghurt: Science and Technology. Pergamon Press Ltd., Oxford.

[18] Schmidt, K. and Bledsoe, K. (1995) Effects of Homogenization Pressure on Physical and Sensory Characteristics of Low Fat Yogurt. Cultured Dairy Products Journal, 30, 7-10. 
[19] Schellhaass, S.M. and Morris, H.A. (1985) Rheological and Scanning Electron Microscopic Examination of Skim Milk Gels Obtained by Fermenting with Ropy and Non-Ropy Strains of Lactic Acid Bacteria. Food Microstructure, 4, 279-287.

[20] Lucey, J.A., Munro, P.A. and Singh, H. (1998) Whey Separation in Acid Milk Gels Made with Glucono-Delta-Lactone: Effects of Heat Treatment and Gelation Temperature. Journal of Texture Studies, 29, 413-426. https://doi.org/10.1111/j.1745-4603.1998.tb00813.x

[21] Aryana, K.J., Plauche, S., Rao, R.M., McGrew, P. and Shah, N.P. (2007) Fat Free Plain Yogurt Manufactured with Inulins of Various Chain Lengths and Lactobacillus acidophilus. Journal of Food Science, 72, M79-M84. https://doi.org/10.1111/j.1750-3841.2007.00302.x

[22] Olson, D.W. and Aryana, K.J. (2008) An Excessively High Lactobacillus acidophilus Inoculation Level in Yogurt Lowers Product Quality during Storage. LWT, Food Science and Technology, 41, 911-918. https://doi.org/10.1016/j.lwt.2007.05.017

[23] Cueva, O. and Aryana, K.J. (2008) Quality Attributes of a Heart Healthy Yogurt. LWT-Food Science and Technology, 41, 537-544. https://doi.org/10.1016/j.lwt.2007.04.002

[24] R-Biopharm AG. An der NeuenBergstraße 17, 64297 Darmstadt. Purchased through: R-Biopharm Inc. 870 Vossbrink Drive Washington, MO 63090, United States of America. Enzytec ${ }^{\mathrm{Tm}}$ Liquid Lactose/D-Galactose Kit (Art. No. E8110). https://food.r-biopharm.com/products/enzytec-liquid-lactose-d-galactose

[25] Tharmaraj, N. and Shah, N.P. (2003) Selective Enumeration of Lactobacillus delbrueckii ssp. bulgaricus, Streptococcus thermophilus, Lactobacillus acidophilus, Bifidobacteria, Lactobacillus casei, Lactobacillus rhamnosus, and Propionibacteria. Journal of Dairy Science, 86, 2288-2296. https://doi.org/10.3168/jds.S0022-0302(03)73821-1

[26] Dave, R.I. and Shah, N.P. (1996) Evaluation of Media for Selective Enumeration of Streptococcus thermophilus, Lactobacillus delbrueckii ssp. bulgaricus, Lactobacillus acidophilus, and Bifidobacteria. Journal of Dairy Science, 79, 1529-1536. https://doi.org/10.3168/jds.S0022-0302(96)76513-X

[27] Calvo, M.M., Montilla, A. and Cobos, A. (1999) Lactic Acid Production and Rheological Properties of Yogurt Made from Milk Acidified with Carbon Dioxide. Journal of the Science of Food and Agriculture, 79, 1208-1212. https://doi.org/10.1002/(SICI)1097-0010(19990701)79:9<1208::AID-JSFA351>3.0.C $\underline{\mathrm{O} ; 2-\mathrm{L}}$

[28] Damin, M.R., Alcantara, M.R., Nunes, A.P. and Oliveira, M.N. (2009) Effects of Milk Supplementation with Skim Milk Powder, Whey Protein Concentrate and Sodium Caseinate on Acidification Kinetics, Rheological Properties and Structure of Nonfat Stirred Yogurt. LWT-Food Science and Technology, 42, 1744-1750. https://doi.org/10.1016/j.lwt.2009.03.019

[29] Venkatesh, K.V., Okos, M.R. and Wankat, P.C. (1993) Kinetic Model of Growth and Lactic Acid Production from Lactose by Lactobacillus bulgaricus. Process Biochemistry, 28, 231-241. https://doi.org/10.1016/0032-9592(93)80039-J

[30] Nagaraj, M., Sharanagouda, B., Manjunath, H. and Manafi, M. (2009) Standardization of Different Levels of Lactose Hydrolysis in the Preparation of Lactose Hydrolyzed Yoghurt. Iranian Journal of Veterinary Research, 10, 132-136.

[31] Knanagaeva, I.S., Tikhomirvo, A.S. and Kulikova, A.K. (1980) Effect of Lactose Hydrolysis on Activity of Lactic Acid Bacteria. Pischevaya Technologiya, 6, 133-134.

[32] Baeve, V.S. (1981) Possibility of Producing Low Lactose Milk Products for Infant 
Feeding Using ß-Gal. Vopeory Itaniya, 2, 63-65.

[33] Whalen, A.C., Gilmore, T.M., Spurgeon, K.R. and Parson, J.G. (1988) Yoghurt Manufactured from Whey-Caseinate Blends and Hydrolyzed Lactose. Journal of Dairy Science, 71, 299-305. https://doi.org/10.3168/jds.S0022-0302(88)79558-2

[34] Fan, L., Forney, C.F., Song, J., Doucette, C., Jordan, M.A., McRae, K.B. and Walker, B.A. (2008) Effect of Hot Water Treatments on Quality of Highbush Blueberries. Journal of Food Science, 73, 292-297. https://doi.org/10.1111/j.1750-3841.2008.00838.x

[35] Hilgendorf, M.J. (1981) Optimization of Fungal Lactase Levels in Yoghurt Manufacturing. Cultured Dairy Products Journal, 16, 5-7.

[36] Davood, N., Dariani, D.N., Frank, J.F. and Lowenstein, M. (1982) Manufacture of Low Lactose Yoghurt by Simultaneous Lactose Hydrolysis and Bacterial Fermentation. Cultured Dairy Products Journal, 17, 18-19, 22.

[37] Matak, K.E., Wilson, J.H., Duncan, S.E., Wilson, E.J., Hackney, C.R. and Sumner, S.S. (2003) The Influence of Lactose Hydrolysis on the Strength and Sensory Characteristics of Vanilla Ice Cream. Transactions of the ASAE, 46, 1589-1593. https://doi.org/10.13031/2013.15621

[38] Cutrim, C.S., Barros, R.F.D., Franco, R.M. and Cortez, M.A.S. (2017) Escherichia coli O157:H7 Survival in Traditional and Low Lactose Yogurt during Fermentation and Cooling Periods. Ciência Animal Brasileira, 18, 1-9. https://doi.org/10.1590/1089-6891v18e-39554

[39] Ding, W.K. and Shah, N.P. (2010) Enhancing the Biotransformation of Isoflavones in Soymilk Supplemented with Lactose Using Probiotic Bacteria during Extended Fermentation. Journal of Food Science, 75, 140-149. https://doi.org/10.1111/j.1750-3841.2010.01526.x

[40] Hamann, W.T. and Marth, E.H. (1984) Survival of Streptococcus thermophilus and Lactobacillus bulgaricus in Commercial and Experimental Yoghurts. Journal of Food Protection, 47, 781-786. https://doi.org/10.4315/0362-028X-47.10.781

[41] Rohm, H., Lechner, F. and Lehner, M. (1990) Microflora of Australian Natural-Set Yoghurt. Journal of Food Protection, 53, 478-480. https://doi.org/10.4315/0362-028X-53.6.478

[42] Akalin, A.S., Fenderya, S. and Akbulut, N. (2004) Viability and Activity of Bifidobacteria in Yoghurt Containing Fructooligosaccharides during Refrigerated Storage. International Journal of Food Science, 39, 613-621. https://doi.org/10.1111/j.1365-2621.2004.00829.x

[43] Donkor, O.N., Henriksson, A., Vasiljevic, T. and Shah, N.P. (2006) Effect of Acidification on the Activity of Probiotics in Yoghurt during Cold Storage. International Dairy Journal, 16, 1181-1189. https://doi.org/10.1016/j.idairyj.2005.10.008

[44] Ben-Yahia, L., Mayeur, C., Rul, F. and Thomas, M. (2012) Growth Advantage of Streptococcus thermophilus over Lactobacillus bulgaricus in Vitro and in the Gastrointestinal Tract of Gnotobiotic Rats. Beneficial Microbes, 3, 211-219. https://doi.org/10.3920/BM2012.0012

[45] Tabasco, R., de Palencia, P.F., Fontecha, J., Pelßez, C. and Requena, T. (2014) Competition Mechanisms of Lactic Acid Bacteria and Bifidobacteria: Fermentative Metabolism and Colonization. LWT-Food Science and Technology, 55, 680-684. https://doi.org/10.1016/j.lwt.2013.10.004

[46] Routray, W. and Mishra, H.N. (2011) Scientific and Technical Aspects of Yogurt Aroma and Taste: A Review. Comprehensive Reviews in Food Science and Food Safety, 10, 208-220. https://doi.org/10.1111/j.1541-4337.2011.00151.x 
[47] Janiaski, D.R., Pimentel, T.C., Cruz, A.G. and Prudencio, S.H. (2016) Strawberry-Flavored Yogurts and Whey Beverages: What Is the Sensory Profile of the Ideal Product? Journal of Dairy Science, 99, 5273-5283.

https://doi.org/10.3168/jds.2015-10097 